\title{
Pengaruh Matematika GASING (Gampang, ASylk, dan menyenaNGkan) pada Materi Perkalian Bilangan Bulat Terhadap Hasil Belajar Peserta Matrikulasi STKIP Surya
}

\author{
Armianti ${ }^{1}$, Indri Yani ${ }^{2}$, Kartika Widuri ${ }^{3}$, Sulistiawati ${ }^{4}$ \\ 1,2,3,4 Mathematics Education Department, Surya Research and Education Center (STKIP \\ Surya), SuRE Building Lt. 4, Gading Serpong, Tangerang, Indonesia \\ Coresponding Author Email: 'Armianti94@gmail.com \\ Author Email: ${ }^{2}$ Indrhy16@gmail.com \\ 3)kartikawiduri768@gmail.com \\ ${ }^{4)}$ sulistiawati@stkipsurya.ac.id
}

DOI: http://dx.doi.org/10.15294/kreano.v7i1.5012

Received : January 2016; Accepted: March 2016; Published: June 2016

\begin{abstract}
Abstrak
Hasil penelitian sebelumnya menunjukkan bahwa masih banyak peserta didik atau siswa yang kebingungan dalam konsep operasi bilangan bulat. Hal ini disebabkan oleh adanya konflik konsep pemahaman operasi aritmatika bilangan bulat dengan pengetahun awal yang mereka miliki. Beberapa kasus di STKIP Surya, peserta matrikulasi juga masih cenderung menghafal tanpa tahu makna dari perkalian itu sendiri. Oleh karena itu, dalam penelitian ini digunakan Matematika GASING (Gampang, ASylk, dan menyenaNGkan) untuk mengatasi permasalahan tersebut. Pembelajaran Matematika GASING untuk bilangan bulat menggunakan alat peraga yang dikenal dengan istilah "Gunung Lembah". Penelitian ini bertujuan untuk mengetahui adanya pengaruh pembelajaran Matematika GASING terhadap hasil belajar pada materi perkalian bilangan bulat. Metode dalam penelitian ini adalah pre-experimental design dengan desain penelitian one-group pretest-posttests. Sampel dalam penelitian ini sebanyak 17 peserta matrikulasi STKIP Surya tahun ajaran 2015/2016 dengan cara purposive sampling. Instrumen penelitian dikembangkan berdasarkan ranah kognitif taksonomi Bloom untuk aspek pemahaman. Hasil penelitian ini adalah terdapat pengaruh penggunaan pembelajaran Matematika GASING. Pengaruh ini tampak dari adanya peningkatan (N-gain) hasil belajar untuk konsep perkalian bilangan bulat yang berada pada kriteria sedang yaitu sebesar 0,59.
\end{abstract}

\begin{abstract}
This research is motivated by the many participants matriculation is still confusion in the concept of integer operations due to conflicts concept of a preliminary understanding that they have the numbers (basic math like addition, multiplication, subtraction, and division of positive integers). Participants matriculation also still tend to memorize without knowing the meaning of multiplication it self. Therefore, the use of mathematical GASING (Easy, fun, and enjoyable) to use props known as "Gunung Lembah". Mathematics GASING at no stage should be controlled matriculation participants to be able to master the material is well known as "Titik Kritis GASING ". The method used is pre-experimental design to study design one-group pretest-posttests. The sample in this study as many as 17 participants matriculation STKIP Surya academic year 2015/2016 by purposive sampling. The results in this study was the effect of the use of learning mathematics are GASING. In addition there is an increase ( $N$-gain) learning outcomes for integer multiplication concept was moderate at 0,59.
\end{abstract}

Keywords: Mathematics GASING, Gunung Lembah, learning outcomes, Multiplication Integer

\section{PENDAHULUAN}

Matematika adalah salah satu cabang ilmu yang dipelajari di semua tingkat satuan pendidikan. Matematika merupakan pelajaran yang penting karena merupakan ratu dan sekaligus pelayan dari segala ilmu. Hal ini menunjukkan pentingnya matematika dalam kehidupan. Namun pada kenyataanya masih saja peserta matrikulasi mengalami kesulitan dalam menggunakan ide-ide dasar, konsep-konsep matematika dalam kehidupan sehari- hari. Hal ini disebabkan karena pembelajaran ma- 
tematika selama ini hanya menekankan pada hasil tidak menekankan pada prosesnya.

Belajar operasi bilangan bulat pada tingkat perguruan tinggi tidak menutup kemungkinan masih adanya peserta matrikulasi yang masih mengalami kebingungan dalam konsep operasi bilangan bulat, hal ini diperjelas oleh Bofferding, 2014, bahwa masih banyak peserta matrikulasi yang kebingungan dalam konsep operasi bilangan bulat dikarenakan terjadi konflik konsep pemahaman awal yang mereka miliki pada bilangan (matematika dasar seperti penjumlahan, perkalian, pengurangan, dan pembagian bilangan bulat positif). Peserta matrikulasi juga masih cenderung menghafal tanpa tahu makna dari perkalian itu sendiri. Dengan demikian diperlukan pembelajaran yang dapat membuat peserta matrikulasi mengerti dan paham konsep-konsep materi pembelajaran serta memberikan pengalaman belajar langsung yang sesuai dengan tingkat kemampuan berpikir matematisnya. Sehingga digunakanlah pembelajaran Matematika GASING (Gampang, ASylk, dan menyenaNGkan).

Matematika GASING (GAmpang aSylk menyenaNGkan) adalah suatu cara belajar matematika secara GAmpang, aSyik, dan menyenaNGkan yang dilakukan secara langkah demi langkah untuk memperolah suatu capaian atau hasil. Shanty dan Wijaya (2012) mendeskripsikan Matematika GASING sebagai proses pembelajaran yang membuat peserta matrikulasi belajar secara easy, fun, and enjoyable. Dalam proses pembelajarannya, pertama-tama peserta matrikulasi dikenalkan dengan benda-benda konkret. Selanjutnya peserta matrikulasi diarahkan ke simbol-simbol abstrak, dan terakhir peserta matrikulasi diajak mencongak sebagai bentuk evaluasi. Tahapan konkret dalam pembelajaran Matematika GASING bertujuan untuk memberikan pengalaman langsung kepada peserta matrikulasi sehingga peserta matrikulasi bisa menyimpulkan sendiri apa yang mereka pelajari.

Pengalaman belajar langsung dapat dilakukan dengan menggunakan media pembelajaran. Media pembelajaran (manipulative materials) adalah suatu alat peraga yang penggunaannya diintegrasikan dengan tujuan dan isi pengajaran yang telah dituangkan dalam GBPP bidang studi matematika dan bertujuan untuk mempertinggi mutu kegiatan belajar mengajar. Dengan kata lain alat peraga matematika adalah alat yang digunakan untuk mempermudah menjelaskan konsep matematika (Rohayati, 2008). Penggunaan media pembelajaran harus tepat dengan tujuan pembelajaran agar pembelajaran berlangsung maksimal. Salah satu media yang dapat digunakan yaitu gunung \& lembah. Dengan menggunakan gunung \& lembah peserta matrikulasi diharapkan mampu memahami arti dari bilangan bulat positif dan negatif serta bisa menyelesaikan persoalan operasi perkalian pada bilangan bulat. Tujuan dari penelitian ini: 1) Untuk mengetahui apakah ada pengaruh pembelajaran Matematika GASING terhadap hasil belajar peserta matrikulasi pada materi perkalian bilangan bulat dan 2) untuk mengetahui bagaimana kualitas peningkatan hasil belajar peserta matrikulasi setelah belajar menggunakan Matematika GASING.

\section{Matematika GASING}

Matematika GASING (GAmpang aSylk menyenaNGkan) adalah suatu cara belajar matematika secara GAmpang, aSyik, dan menyenaNGkan yang dilakukan secara langkah demi langkah untuk memperolah suatu capaian atau hasil. Prof. Yohanes Surya (Dalam Shanty dan Wijaya, 2012) mendeskripsikan bahwa dalam Matematika GASING, ketika belajar suatu materi ada titik kritis yang harus dilewati. Titik kritis yang dimaksud adalah titik kritis GASING. Setelah melalui titik kritis dengan baik, peserta matrikulasi tidak akan mengalami kesulitan untuk mengerjakan soal dari materi yang diberikan tersebut. Titik kritis GASING pada materi perkalian bilangan bulat, yaitu peserta matrikulasi mengerti konsep ambil/taruh gunung/lembah. Langkah-langkah untuk mencapai titik kritis GASING materi perkalian bilangan bulat ada 4 poin, yaitu peserta matrikulasi harus melewati tangga pertama yaitu garis bilangan. Selanjutnya tangga kedua, peserta matrikulasi harus menguasai operasi bilangan bulat pada garis bilangan, kemudian tangga ketiga, peserta matrikulasi menguasai konsep gunung dan lembah, dan tangga keempat peserta matrikulasi mengu- 
asai operasi bilangan bulat dengan konsep ambil/taruh gunung/lembah. Diskripsi dari langkah-langkah titik kritis GASING yang telah dijelaskan di atas dapat dilihat pada gambar 1.

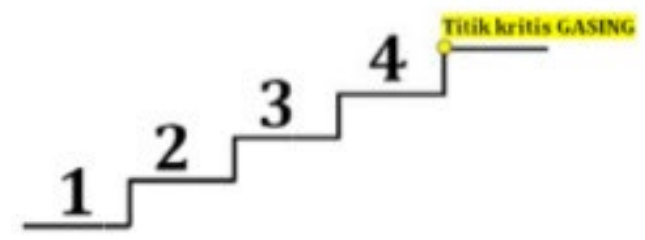

Gambar 1. Diskripsi tangga untuk mencapai titik kritis GASING.

(Sumber: Modul Matematika GASING SD Bagian 2)

Dalam tulisan ini disajikan beberapa contoh pembelajaran perkalian bilangan bulat. Pemahaman konsep perkalian bilangan bulat dimulai dari tahap konkret kemudian dilanjutkan dengan tahap abstrak atau penyajian dalam bahasa matematika. Pada penelitian ini pengenalan konsep perkalian secara konkret menggunakan alat peraga gunung lembah. Alat peraga gunung lembah adalah suatu alat bantu pembelajaran yang berbentuk seperti gunung yang dianggap sebagai bilangan bulat positif $(+)$ dan lembah yang dianggap sebagai bilangan bulat negatif (-). Diskripsi dari alat peraga gunung lembah yang telah dijelaskan dapat dilihat dari gambar 2,3 , dan 4 .

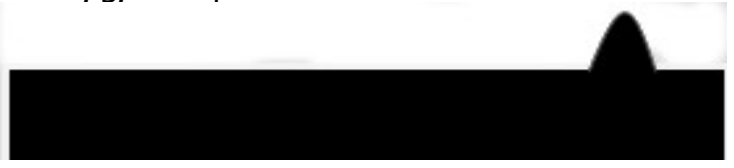

Gambar. 2 alat peraga gunung sebagai bilangan bulat positif.

(Sumber: Modul Matematika GASING SD Bagian 2)

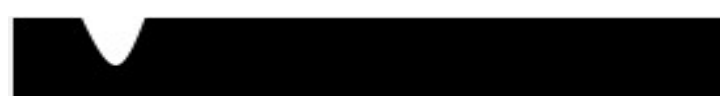

Gambar. 3 alat peraga lembah sebagai bilangan bulat negatif.

(Sumber: Modul Matematika GASING SD Bagian 2)

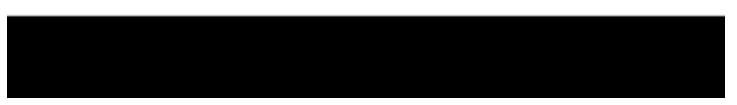

Gambar. 4 alat peraga gunung lembah sebagai bilangan nol (o).

(Sumber: Modul Matematika GASING SD Bagian 2)
Sebelum masuk ke operasi perkalian bilangan bulat dengan alat peraga gunung lembah, terlebih dahulu diajarkan pengurangan dan penjumlahan bilangan bulat dengan gunung lembah. Pada operasi pengurangan, untuk pengurangan bilangan yang tidak Cukup maka harus menggali. Misalnya $3-5=-2$, artinya ada tiga gunung ingin diambil lima gunung, karena hanya punya tiga gunung maka harus menggali kekurangannya sebanyak dua gunung, setelah digali dua gunung akhirnya terbentuk dua lembah. Setelah kiranya peserta matrikulasi bisa operasi pengurangan dan penjumlahan dengan gunung lembah barulah masuk ke operasi perkalian. Pada operasi perkalian tanda negatif artinya "diambil" dan positif artinya "ditaruh", Berikut ini contoh pengenalan konsep perkalian bilangan bulat secara konkret.

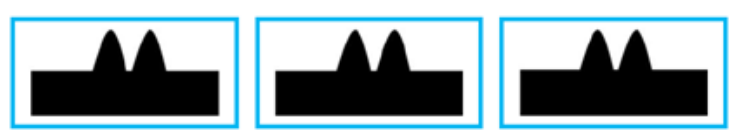

Gambar. 5. Konkret perkalian $3 \times 2$ (Sumber: Modul Matematika GASING SD Bagian 2)

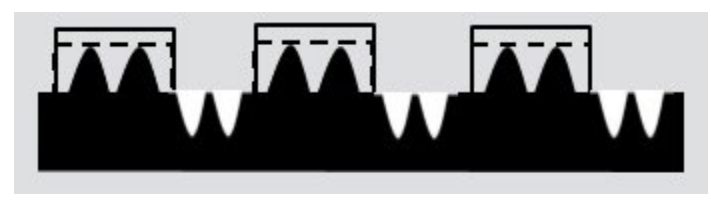

Gambar. 6. konkret perkalian (-3) $\times 2$

(Sumber: Modul Matematika GASING SD Bagian 2)

Dalam pembelajaran dengan Matematika GASING dapat dikatakan perkalian $3 \times 2$ artinya "ditaruh dua gunung sebanyak 3 kali" sedangkan perkalian $(-3) \times 2$ artinya "diambil 2 gunung sebanyak 3 kali.

\section{Hasil Belajar Matematika}

Hasil belajar merupakan bagian terpenting dalam suatu pemebelajaran. Menurut Sudjana (2009) menyatakan bahwa pada dasarnya hasil belajar merupakan perubahan tingkah laku sebagai hasil belajar yang mencakup aspek kognitif, afektif, dan psikomotorik. Sedangkan menurut Dimyati dan Mudjino (2006) menyatakan bahwa hasil belajar me- 
rupakan hasil dari suatu interaksi antara mengajar dan belajar. Pada proses mengajar yang dilakukan seorang guru diakhiri dengan proses evaluasi hasil belajar. Sedangkan pada peserta matrikulasi, hasil belajar merupakan berakhirnya pengajaran dari proses belajar. Berdasarkan pengertian hasil belajar di atas, dapat disimpulkan bahwa hasil belajar adalah kemampuan-kemampuan yang dimiliki peserta didik setelah menerima pengalaman belajarnya. Kemampuan yang dimaksud tersebut mencakup aspek kognitif, afektif, dan psikomotorik. Hasil belajar bisa dilihat melalui proses evaluasi yang bertujuan untuk mengetahui sejauh mana peserta didik mencapai tujuan pembelajaran. Hasil belajar yang akan diteliti dalam penelitian ini adalah hasil belajar kognitif yang mencakup dua tingkatan yaitu pengetahuan ( $\left.C_{1}\right)$ dan pemahaman ( $C_{2}$ ). Instrumen yang digunakan untuk mengukur hasil belajar peserta matrikulasi pada aspek kognitif adalah tes.

\section{METODE}

Metode yang digunakan dalam penelitian ini adalah pre-experimental dengan desain penelitian one-group pretest-postests. Penelitian kuantitatif one group pretest-postest design adalah penelitian dengan membandingkan nilai pretes dan postes (Sugiyono, 2010). Desain penelitian ini adalah:

$\underset{O_{1}}{ } \quad \boldsymbol{X} \quad \boldsymbol{O}_{\mathbf{2}}$
Keterangan:
$\mathrm{O}_{1}:$ nilai pretes
$\mathrm{X}:$ perlakuan pembelajaran Matematika GASING
$\mathrm{O}_{2}$ : nilai postes

Subyek dalam penelitian ini adalah peserta matrikulasi STKIP Surya angkatan 2015/2016 dengan jumlah 17 orang pada Oktober 2015. Pemilihan kelas sebagai sampel dalam penelitian ini bersifat purposive sampling. Alat pengumpulan data yang digunakan dalam penelitian ini yaitu instrumen tes. Instrumen tes digunakan untuk mengambil data pretes dan postes dengan pembelajaran matematika gasing. Sebelum digunakan instrumen tes diujicobakan terlebih dahulu untuk melihat validitas, reliabilitas, daya pembeda, dan tingkat kesukaran. Uji validitas dalam penelitian ini dengan menggunakan rumus korelasi Product Moment Pearson. Uji reliabilitas untuk tipe soal uraian menggunakan rumus Cronbach's Aplha.

Untuk uji tingkat kesukaran digunakan rumus sebagai berikut.

$$
T K=\frac{S A+S B}{L A+I B}(\text { Sundayana, } R ., 2014)
$$

Keterangan:

$T K$ : tingkat kesukaran

$S A$ : jumlah skor kelompok atas

$S B$ : jumlah skor kelompok bawah

IA : jumlah skor ideal kelompok atas

$B$ : jumlah skor ideal kelompok bawah berikut.

Klasifikasi tingkat kesukaran sebagai

Tabel 1. Kriteria Tingkat Kesukaran

\begin{tabular}{cc}
\hline Tingkat Kesukaran & Interpretasi \\
\hline$T K \leq 0,00$ & Terlalu Sukar \\
$0,00<T K \leq 0,30$ & Sukar \\
$0,30<T K \leq 0,70$ & Sedang \\
$0,70<T K \leq 1,00$ & Mudah \\
$T K=1,00$ & Terlalu mudah \\
\hline
\end{tabular}

Prosedur dalam penelitian ini diantarannya: 1) mengidentifikasi masalah dan tujuan, 2) menentukan desain penelitian sesuai masalah dan tujuan, 3)menyusun instrumen tes dilanjutka dengan validasi, 4) memberikan pretes konsep perkalian bilangan bulat, 5) memberikan pembelajaran sesuai tahapan titik kritis gasing, 6) memberikan postes konsep perkalian bilangan bulat, 7) melakukan analisi terhadap hasil tes, 8) membuat kesimpulan dari hasil penelitian, 9) menulis laporan penelitian.

Analisis data dalam penelitian ini berupa analisis kuantitatif. Analisis dilakukan terhadap hasil pretes dan postes untuk tes konsep perkalian bilangan bulat. Uji statistik yang digunakan adalah uji non parametrik untuk dua sampel yang berkorelasi (2 related sample). Uji non parametriknya adalah uji wilcoxon. Penelitian menggunakan uji non parametrik wilcoxon karena asumsi-asumsi untuk menggunakan uji parametrik, seperti normalitas dan homogenitas tidak dapat dipenuhi. 
Desain penelitian one-group pretest-postest mengakibatkan asumsi homogenitas tidaklah mungkin dipenuhi dari awal, sehingga dalam penelitian ini tidak perlu dilakukan uji normalitas.

Analisa data kuantitatif selanjutnya adalah untuk melihat besarnya peningkatan sebelum dan sesudah pembelajaran dengan Matematika GASING yang dihitung dengan rumus gain ternormalisasi yang dikembangkan oleh Meltzer (2002). Rumus gain tersebut seperti berikut ini:

\section{$N$-gain $(g)=($ skor postes-skor pretes $) /($ skor ideal- skor pretes)}

Nilai gain yang diperoleh selanjutnya diinterpretasikan menurut klasifikasin indeks $\mathrm{N}$-gain menurut Hake (1999) dapat dilihat pada Tabel 2.

Tabel 2. Interpretasi Indeks N-gain

\begin{tabular}{cc}
\hline Indeks N-gain $(g)$ & Interpretasi \\
\hline$g \geq 0,7$ & Tinggi \\
$0,3 \leq g<0,7$ & Sedang \\
$g<0,3$ & Rendah \\
\hline
\end{tabular}

\section{HASIL DAN PEMBAHASAN}

\section{Hasil Uji Coba Instrumen}

Sebelum penelitian dilakukan kepada peserta matrikulasi, terlebih dahulu peneliti melakukan uji validitas dan reliabilitas instrumen tes yang akan digunakan. Jumlah soal tes diberikan sebanyak 20 butir soal. Dari 20 butir soal ini dilakukan uji validitas dengan menggunakan microsoft excel. Dari analisis uji validitas diperoleh 12 soal valid dan 8 tidak. Soal yang valid bernomor $4,5,6,7,9,10,11,13,15$, $17,18,20$.

Setelah melakukan uji validitas peneliti melakukan uji reliabilitas dengan menggunakan rumus Cronbach's Aplha. Dari perhitungan didapat nilai reliabilitas sebesar 0,9782 sehingga menurut klasifikasi koefisien reabilitas, nilai ini termasuk kategori tinggi. Nilai reliabilitas yang didapat terbilang tinggi yang artinya instrumen yang dibuat ajeg, tetap dan dipercaya. Setelah didapatkan nilai reliabilitas maka dilakukan lagi perhitungan untuk mencari tingkat kesukaran instrumen. Hasil perhitungan dari tingkat kesukaran dapat dilihat pada Tabel 3.

\begin{tabular}{ccc}
\multicolumn{3}{c}{ Tabel 3. Hasil Analisi Uji Coba Instrumen } \\
\hline Nomor Soal & TK & DP \\
\hline 4 & Mudah & Baik \\
5 & Mudah & Baik \\
6 & Mudah & Baik \\
7 & Sedang & Sangat baik \\
9 & Mudah & Baik \\
10 & Mudah & Sangat baik \\
11 & Sedang & Sangat baik \\
13 & Sedang & Sangat baik \\
15 & Mudah & Sangat baik \\
17 & Sedang & Sangat baik \\
18 & Sedang & Sangat baik \\
20 & Sedang & Sangat baik \\
\hline
\end{tabular}

Uii Hipotesis dengan Analisis Skor Hasil Belajar Matematika Peserta matrikulasi.

Di sini akan dilakukan analisis hasil skor pretest, postest dan gain (peningkatan). Untuk menganalisis data digunakan Ms. Excel dan software PSPP18.

Hasil Kemampuan awal (Pretest) dan postest

Setelah analisis instrumen selesai dan soal siap diguanakan, maka akan mendapatkan hasil berupa skor pretes dan postest. Skor pretest dan postest ini nantinya akan digunakan untuk mengetahui rata-rata, standar deviasi, nilai maximum dan minimum. Adapun hasil perhitungan statistika deskriptif dapat dilihat pada Tabel 4 .

Tabel 4. statistika deskriptif pretest dan postest

\begin{tabular}{cccccc}
\hline Aspek & $\mathrm{N}$ & $\begin{array}{c}\text { Mini- } \\
\text { mum }\end{array}$ & $\begin{array}{c}\text { Maxi- } \\
\text { mum }\end{array}$ & $\begin{array}{c}\text { Rata- } \\
\text { rata }\end{array}$ & $\begin{array}{c}\text { Std. } \\
\text { Deviation }\end{array}$ \\
\hline Pretest & 17 & 10 & 65 & 30,88 & 17,251 \\
Postest & 17 & 35 & 100 & 71,76 & 21,061 \\
\hline
\end{tabular}

Dari tabel di atas diketahui rata-rata kemampuan awal hasil belajar matematika peserta matrikulasi sebelum diberi perlakuan adalah 30,88, skor terendahnya 10 dan skor 
tertinggi 65 . Sedangkan rata-rata posttest 71,76 , skor terendahnya 35 dan skor tertingginya 100. Skor ideal yang harus dicapai peserta matrikulasi yaitu 100. Dari tabel tersebut terlihat bahwa hasil belajar awal dan hasil belajar akhir sangat berbeda. Terlihat dari peningkatan skor rata-rata posttest yang meningkat menjadi 71,76 .

Uii Normalitas Skor Pretes dan Postest Hasil Belajar Peserta Matrikulasi.

Dalam uji normalitas skor pretest dan postest digunakan uji Shapiro-wilk dikarenakan $\mathrm{n}<$ 30. Pasangan hipotesis yang diuji adalah

$\mathrm{H}_{\mathrm{o}}$ : Sampel berasal dari populasi yang berdistribusi normal

$\mathrm{H}_{\mathrm{a}}$ : Sampel berasal dari populasi yang tidak berdistribusi normal

Adapun kriteria pengambilan keputusan adalah taraf signifikansi lebih dari 0,05 maka data berdistribusi normal dan taraf signifikansi kurang dari 0,05 berarti data tidak berdistribusi normal. Pengujian ini menggunakan software SPSS. Hasil perhitungan uji normalitas dapat dilihat pada Tabel 5 .

Dari Tabel 5 diperoleh signifikansi nilai pretes sebesar $0,042<0,05$ yang berarti data pretes tidak berdistribusi normal. Untuk hasil postest diperoleh signifikansi sebesar 0,294 > 0,05 yang berarti data berdistribusi normal. Karena satu data tidak berdistribusi normal maka dapat disimpulkan data-data tersebut tidak normal, sehingga uji statistik yang digunakan selanjutnya yaitu uji-wilcoxon.

\section{Uji Perbedaan Rata-rata Hasil Belajar}

Uji wilcoxon merupakan uji non parametrik untuk dua sampel yang berkorelasi untuk data yang termasuk ordinal. Data dalam penelitian tergolong ke dalam data ordinal. Pasangan uji hipotesisnya sebagai berikut:

$\mathrm{H}_{0}$ : Tidak terdapat perbedaan rata-rata hasil belajar peserta matrikulasi sebelum dan sesudah diberi pembelajaran dengan Matematika GASING.

$\mathrm{H}_{\mathrm{a}}$ : Terdapat perbedaan rata-rata hasil belajar peserta matrikulasi sebelum dan sesudah diberi pembelajaran dengan Matematika GASING.

Kriteria pengujian hipotesisnya pada taraf signifikansi $\alpha=5 \%$ adalah jika nilai Asymp. Sig. (2-tailed) $>\alpha$ maka $\mathrm{H}_{0}$ diterima. Sebaliknya, jika nilai Asymp. Sig. (2-tailed) < $\alpha$ maka $\mathrm{H}_{\mathrm{o}}$ ditolak. Pengujian uji wilcoxon dengan program spss dapat dilihat hasilnya pada Tabel 6 .

Dari Tabel 6 diperoleh nilai Asymp. Sig. (2-tailed) sebesar 0,000. Karena nilai sig 0,000 $<0,05$ dapat disimpulkan bahwa ada perbedaan rata-rata hasil belajar peserta matrikulasi sebelum dan sesudah diberi perlakuan dengan Matematika GASING.

Peningkatan (N-Gain) hasil belajar Matematika Peserta Matrikulasi dengan Matematika GASING.

Untuk melihat peningkatan hasil belajar peserta matrikulasi dalam perkalian bilangan bulat, analisis yang digunakan adalah dengan menghitung selisih skor pretes dan skor postes untuk perkalian bilangan bulat. Untuk me-

Tabel 5. Uji Normalitas Pretest dan Postest

\begin{tabular}{cccccc}
\hline \multirow{2}{*}{ Aspek } & \multicolumn{3}{c}{ Shapiro-wilk } & \multirow{2}{*}{ Keputusan } & kesimpulan \\
\cline { 2 - 4 } & Statistic & df & Sig. & & \\
\hline Pretest & 0,887 & 17 & 0,042 & $\mathrm{H}_{0}$ ditolak & Tidak normal \\
Postest & 0,938 & 17 & 0,294 & $\mathrm{H}_{0}$ diterima & Normal \\
\hline
\end{tabular}

Tabel 6. Uji perbedaan rata-rata hasil belajar Peserta Matrikulasi

\begin{tabular}{|c|c|c|c|c|}
\hline Aspek & Tes & $\begin{array}{c}\text { Asymp. } \\
\text { Sig. } \\
\text { (2-tailed) }\end{array}$ & kesimpulan & Keterangan \\
\hline $\begin{array}{l}\text { Hasil } \\
\text { belajar }\end{array}$ & $\begin{array}{l}\text { Pretes } \\
\text { Postes }\end{array}$ & 0,000 & $\mathrm{H}_{\mathrm{o}}$ ditolak & $\begin{array}{l}\text { Terdapat } \\
\text { perbedaan }\end{array}$ \\
\hline
\end{tabular}


lihat peningkatan ini digunakan uji terhadap satu perlakukan yaitu uji t. Uji t dapat digunakan jika data memiliki sebaran normal.

Uji normalitas untuk peningkatan hasil belajar peserta matrikulasi yang belajar menggunakan pembelajaran Matematika GASING dihitung menggunakan SPSS yaitu uji satu sampel dengan uji Shapiro-wilk. Pasangan hipotesisyang diuji adalah:

$\mathrm{H}_{\mathrm{o}}$ : Sampel berasal dari populasi yang berdistribusi normal

$\mathrm{H}_{\mathrm{a}}$ : Sampel berasal dari populasi yang berdistribusi tidak normal

Kriteria pengujian adalah taraf signifikansi lebih dari 0,05 maka data berdistribusi normal dan taraf signifikansi kurang dari 0,05 berarti data tidak berdistribusi normal. Hasil perhitungan normalitas N-Gain dapat dilihat pada Tabel 7.

Dari Tabel 7. terlihat bahwa nilai signifikansi sebesar 0,099 > 0,05 yang artinya data berdistribusi normal. Selanjutnya dilakukan uji hipotesis satu rata-rata menggunakan ujit.

Untuk menjawab hipotesis bagaimana rata-rata peningkatan hasil belajar peserta matrikulasi setelah belajar dengan matematika GASING, dilakukan uji satu rata-rata. Uji yang digunakan adalah uji t karena asumsi uji ini dapat dilakukan yaitu normlitas terpenuhi. Pasangan hipotesis statistiknya sebagai berikut:

$\mathrm{H}_{\mathrm{o}}$ Rata-rata peningkatan hasil belajar tentang perkalian bilangan bulat dengan pembelajaran Matematika GASING minimal kriteria sedang ( $\mu \geq 0,3$ )

$\mathrm{H}_{\mathrm{a}}$ : Rata-rata peningkatan hasil belajar tentang perkalian bilangan bulat dengan pembelajaran Matematika GASING di bawah kriteria sedang ( $\mu<0,3$ )

Kriteria pengujian hipotesis adalah $\mathrm{H}_{0}$ ditolak jika $\mathrm{t}_{\text {hitung }}<-\mathrm{t}_{\text {tabel }}$ dan $\mathrm{H}_{\mathrm{o}}$ diterima jika $\mathrm{t}_{\text {hi- }}$ tung $>-t_{\text {tabel. }}$. Hasil uji satu rata-rata skor $\mathrm{N}$-gain hasil belajar tentang perkalian bilangan bulat dapat dilihat pada Tabel 8.

Dari tabel diatas dapat dilihat nilai $t_{\text {hitung }}$ $=4,255$ dan nilai sig. (2-tailed) $=0,001<0,05$, maka $\mathrm{H}_{\mathrm{o}}$ diterima. Hal ini berarti rata-rata peningkatan hasil belajar dengan pembelajaran
Matematika GASING minimal sedang. Selain itu berdasarkan hasil perhitungan dengan SPSS diperlihatkan bahwa rata-rata $\mathrm{N}$-gain hasil belajar adalah 0,59 dan simpangan baku adalah 0,28.

Penelitian ini dilakukan dengan menggunakan pembelajaran Matematika GASING untuk memberikan pengaruh terhadap hasil belajar matematika peserta matrikulasi. Aspek yang dilihat dalam penelitian ini yaitu aspek kognitif berupa indikator kemampuan pemahaman. Sampel dalam penelitian ini adalah peserta matrikulasi yang sebelumnya sudah pernah belajar materi perkalian di sekolah. Kegiatan penelitian ini dimulai dengan pemberian pretest kepada peserta matrikulasi. Dari pretest didapat ata-rata hasil sebesar 30,88. Dari hasil pretest ditemukan kesalahankesalahan yang banyak terjadi ketika mereka mengerjakan soal. Kesalahan pengerjaan soal tersebut dapat dilihat pada gambar dibawah ini.

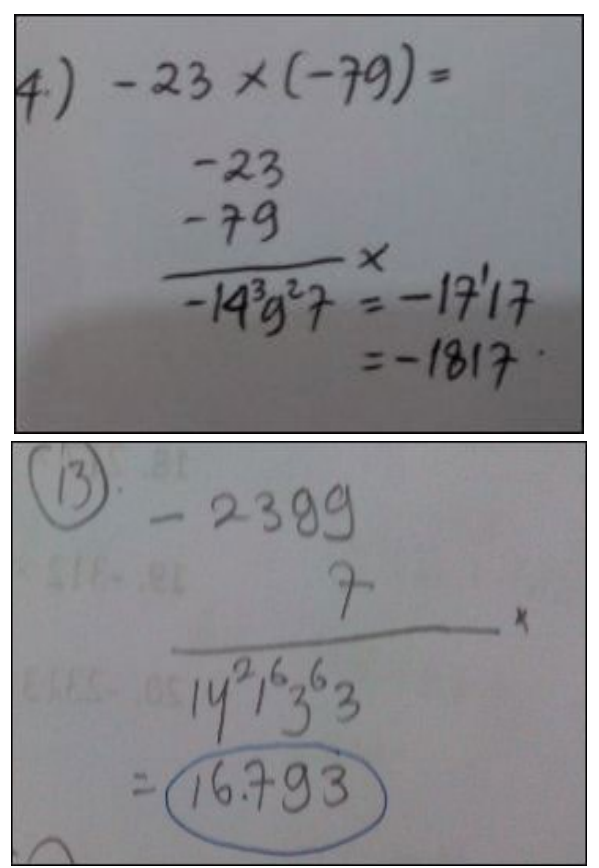

Gambar 1. Hasil kerja peserta matrikulasi pada saat pretes

Dari gambar diatas terlihat bahwa yang mereka asumsikan yaitu ketika bilangan negatif dikali bilangan negatif hasilnya negatif, kesalahan lainnya yaitu ketika bilangan negatif dikali positif mereka bigung akan menghasilkan negatif atau positif karena di salah satu angka ada negatif dan satunya ada positif 
selain itu kurangnya ketelitian dalam menghitung perkalian. Selanjutnya setelah diberikan perlakuan dengan matematika GASING dengan menggunakan gunung lembah peserta matrikulasi bisa menyimpulkan sendiri bahwa jika bilangan negatif dikali bilangan negatif hasilnya positif, bilangan negatif dikali positif hasinya negatif. Hal tersebut diketahui dari peningkatan rata-rata hasil postes sebesar 71,76 dan dapat dilihat pada gambar lembar kerja siswa dibawah ini.

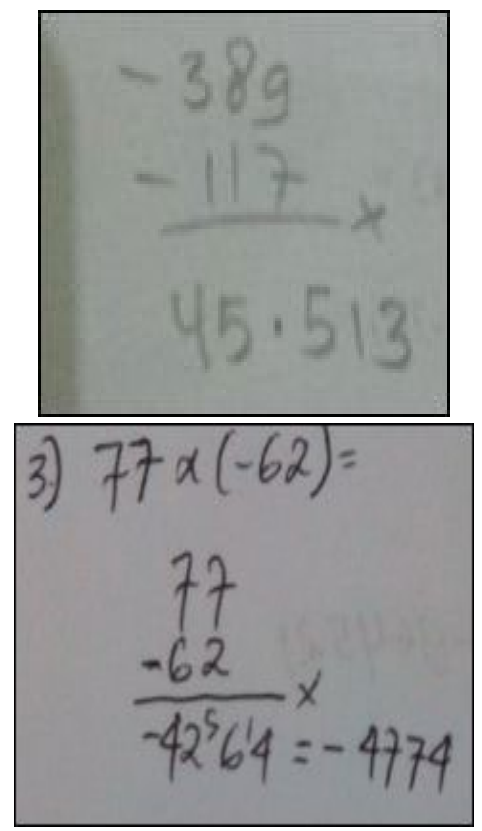

Gambar 2. Hasil kerja peserta matrikulasi pada saat postes

Dari kegiatan pembelajaran dan analisis data didapat bahwa terdapat perbedaan hasil belajar peserta matrikulasi sebelum dan sesudah diberi perlakuan dengan Matematika GASING. Perbedaan ini dapat terjadi sebagai akibat dari perlakuan yang diberikan kepada peserta matrikulasi. Dan juga hal ini dapat lihat dari rata-rata peningkatan hasil belajar sebesar 0,59 yang termasuk dalam kategori sedang.

Berdasarkan hasil dan pembahasan diatas, maka diperoleh beberapa kesimpulan terkait pertanyaan penelitian yang diajukan. Kesimpulan dalam penelitian ini diantaranya yaitu terdapat perbedaan rata-rata hasil belajar peserta matrikulasi sebelum dan sesudah diberi perlakuan dengan Matematika GASING dan rata-rata peningkatan hasil belajar peserta matrikulasi dalam perkalian bilangan bulat masuk dalam kategori minimal sedang.

Berdasarkan hasil dan pembahasan serta kesimpulan diatas, nampak bahwa peningkatan hasil belajar peserta matrikulasi tentang konsep perkalian bilangan bulat tergolong sedang. Sehingga pembelajaran Matematika GASING dengan menggunakan alat peraga gunung lembah dapat dijadikan alternatif dalam pembelajaran perkalian pada bilangan bulat.

\section{DAFTAR PUSTAKA}

Bofferding, L. (2014). Negative integer understanding: Characterizing first graders' mental models. Journal for Research in Mathematics Education, 45(2), 194-245.

Rohayati, A. (2008). Handout Mata Kuliah Pembelajaran Matematika. Bandung

Sugiyono. (2010). Metode Penelitian pendidikan. Bandung: Alfabeta

Sundayana, R. (2014). Statistika Penelitian Pendidikan. Bandung: CV Alfabeta

Shanty, N.O., \& Wijaya, S., (2012). Rectangular Array Model Supporting Students Spatial Structuring in Learning Multiplication. Journal on Mathemathics Education (IndoMS-JME), 3(2), 174-186.

Sudjana, N. (2009). Penilaian Hasil Proses Belajar Mengajar. Bandung: Penerbit Remaja Rosdakarya.

Dimyati \& Mudjiono. (2006). Belajar dan Pembelajaran. Jakarta: Penerbit Rineka Cipta. 